\title{
The Binding Force of International Legal Standards in the Face of the Recurrent Practice of Soft Law
}

\section{Introduction}

The intention of states and international organizations which make use of the instruments of soft law, upon recognition of such conduct being in compliance with international standards, is to influence their mutual conduct in a normative, permissive or prohibitive manner. The practice of adopting acts that fall within the domain of soft law can help to revive international initiatives of a normative nature, allowing the extension of their use to instances of a higher or lower level. But acts of this kind can very well be used as acts of sabotage. It seems that one of the basic functions of such instruments is to create grounds for further work aimed at developing and formulating tools and solutions belonging to the realm of the hard law, i.e they may constitute acts preparatory to subsequent decisions, at the same time, however, they do not constitute a legal basis of derivatives. ${ }^{1}$

Such instruments may also replace hard law in some cases (the role of substitution). In this case, the practice of soft law contributes to preparing the ground for the intended legislative process. Acts belonging to the sphere of soft law do not in themselves generate legal consequences, except that they must be more clearly defined at a later stage in the form of acts issued by the relevant institutions. ${ }^{2}$

1 T. Olawale Elias, Modern Sources of International Law, in Transnational Law in a Changing Society - Essays in Honor of Philip C. Jessup, New York - London 1972, p. 49; K. Skubiszewski, The elaboration of general multilateral conventions and of non-contractual instruments having a normative function or objective, "Annuaire de l'Institut de droit international" 1985, vol. 61(1), p. 101; M. Lachs, Some Reflections on Substance and Form in International Law, in Transnational Law..., op. cit., p. 109; B.S. Diallo, The role and place of soft law in the international legal system, in Wybrane problemy prawa materialnego i procesowego. Teoria i praktyka, ed. K. Konopka, J. Mucha, vol. IV, Poznań 2016, pp. 68-76.

2 For exemple the Vienna Convention on the Law of Treaties defines a treaty as an agreement that is, among other things, "governed by international law" [Vienna Convention on the Law 
80 | Adam Mickiewicz University Law Review

\section{The doctrine and the development of soft law}

Soft law is a doctrinal concept derived from public international law. ${ }^{3}$ Originally conceived as a set of sentences with an attenuated or non-existent binding force, soft law is now conceived as an encompassing concept capable of bringing together all phenomena far from an idea of law as a system of norms sanctioned by the State. Soft law recommends a model of behavior to its recipients, a particular technique for formulating statements embodied in informal acts. In this sense, it differs considerably from the legal norm. ${ }^{4}$ Nevertheless, the recommended technique re-establishes links with the legal norm in the light of the functions it ensures; soft law is understood as an accessory and subsidiary technique to hard law. Can this continuation of hard law by other means not be totally integrated with the legal order? The legal order makes soft law a graduated reception, which oscillates between the absence of consideration and the punctual acceptance of its effects. Soft law is generally excluded from the litigation of excess power because of its non-prescriptive nature, but when envisaged as a source of responsibility of the State in the context of unlimited litigation, subject to judicial review, soft law reflects the ambivalence of the international legal order. Soft law is a set of rules whose "jurisdiction" is discussed. They are non-binding rules of law, which is a priori contrary to the essence of the law. The concept of soft law finds application in particular in international law, environmental law, constitutional law and in contemporary laws. ${ }^{5}$

of Treaties, Art. 2.1(1)(a), May 23, 1969, 1155 U.N.T.S. 331]. This raises the question of what constitutes international law. The statute of the International Court of Justice is probably the most accepted source for a definition of what constitutes international law, and it lists several sources including "international conventions [...] establishing rules expressly recognized by [...] states" [Statute of the International Court of Justice Art. 38(1)(a); hereinafter ICJ Statute]. Thus an agreement is a treaty if it is governed by international law, and international Law is defined as including treaties. It is generally accepted that an agreement is a treaty and therefore is binding under international law if the states involved intend it tobe so. Although one can certainly imagine ambiguities in this pragmatic definition and disputes among states about the legal status of an agreement, it is generally the case that the parties to an agreement have a shared perspective on whether it is binding on them.

3 R.R. Baxter, International Law in "Her Infinite Variety", "The International and Comparative Law Quarterly"1980, vol. 29, no. 4, p. 549; J. Klabbers, The Undesirability of Soft Law, "Nordic Journal of International Law"1998, vol. 67, p. 385; A. Pellet, Le "bon droit" et l'ivraie - plaidoyer pour l'ivraie (Remarques sur quelques problèmes de méthode en droit international du développement), in Le droit des peuples à disposer d'eux-mêmes: méthodes d'analyse du droit international. Mélanges offerts à Charles Chaumont, Paris 1984, pp. 465-493.

$4 \mathrm{M}$. Virally, La distinction entre textes internationaux ayant une portée juridique entre leurs acteurs et textes qui en sont dépourvus, "Annuaire de l'Institut de droit international"1983, vol. 60-I, II, pp. 166-257, 328-357.

5 P.M. Dupuy, Soft Law and the International Law of the Environment, "Michigan Journal of International Law"1991, vol. 12, p. 420; S. Atapattu, International Environmental Law and Soft 
A text creates soft law when it merely advises without a legally required obligation. Two categories of texts are used in the relations between the subjects of international law; on one hand, instruments creating legal obligations (treaties, conventions, agreements) and on the other hand, legally non-binding texts primarily expressing a political will. ${ }^{6}$ The second category includes declarations, resolutions and other acts of international institutions or conferences. This expression of the will of the subjects of international law, principally the States, which is not legally binding, is generally called soft law. Indeed, soft law rules can be found in treaties, which in their entirety are compulsory. Moreover, the increasingly frequent creation of soft law rules, embodied in formally non-binding instruments or in international conventions is one of the main features of current law. This is the case, in particular, for measures to protect the environment, for several reasons. In the first place, unlike many other branches of international law, the environment concerns all areas of life within States, including economic activities, without necessarily affecting or even prioritizing international relations. Secondly, the protection of the environment implies the adoption of medium and long-term measures regulating matters that normally fall within the exclusive competence of States, such as the conservation of biological diversity. ${ }^{7}$ In most cases, these provisions require not only the adaptation of national legislation and institutions, but also the development of the capacities of local authorities to implement them and the allocation of the necessary funds for this purpose. As not only the resources but also the capacity to fulfill these obligations may vary from one State to another, the acceptance of „hard” obligations would be unrealistic, so that the adoption of soft law rules is „preferable.” Soft law appeared at a time when positivist theories were compelled to confront the regulation of new legal issues that formerly belonged to the domaine reserve. Since then, the academy has revisited the sources of international law in considering soft law as a source that questions the canonical basis of international law, thus breaking the ideal of hard legalization and introducing different degrees of normative intensity. ${ }^{8}$ Soft law has triggered doctrinal debates on the

Law: A New Direction or A Contradiction?, in Non-State Actors, Soft Law and Protective Regimes from the Margins, ed. C.M. Bailliet, Cambridge 2012, pp. 200-226.

6 A.E. Boyle, Some Reflections on the Relationship of Treaties and Soft Law, "The International and Comparative Law Quarterly"1999, vol. 48, p. 901. “The traditional sources of international law are frequently attacked as being too narrow, backward looking, and at any rate, incapable of coping with the modern problems of international relations". V. E. Riedel, Standards and Sources. Farewell to the Exclusivity of the Sources Triad in International Law? "European Journal of International Law"1991, vol. 2, p. 58.

7 R. Andorno, The Invaluable Role of Soft Law in the Development of Universal Norms in Bioethics, Paper at a Workshop jointly organized by the German Ministry of Foreign Affairs and the German UNESCO Commission, Berlin 2007, www.unesco.de/.

8 M. Virally, Sur la notion d'accord, in Festschrift fur Rudolf Bindschedler (Mélanges), ed. E. Diaz, Bern 1980, pp. 159-172; F. Roessler, Law, de facto agreements and declarations of principle in international economic relations, "German Yearbook of International Law" 1978, pp. 27-73; 
difference between soft law and hard law, rooted in positions adopted on the basis of the foundations or sources of international law or the process of lawmaking. ${ }^{9}$ Some authors rely on a binary distinction between legal and non-legal rules, while others choose the idea of graduated normativity, or a continuum, or the existence of a penumbra in which soft law has its being. Soft law instruments can even be adopted by new actors involved in the processes of informal international lawmaking, with different degrees of authority, as the new unacknowledged legislators of the world. Soft law also has different functions, covering the inception of law and the interpretation and adaptation of hard law, and it is found in the delegation of functions conferred on international organs charged with developing international law. Soft law has even found its way into legal institutions and international organizations, endowing them with soft responsibility and soft instruments of monitoring and enforcement. In light of these comments and despite its critics, soft law is here to stay. ${ }^{10}$

\section{Soft law as a privileged instrument in the actions of international actors}

Soft law can contribute to the development of hard law or partially replace it, without exposing its sources, but at the same time, it compromises its integrity and rigor. Acts in the field of soft law are undoubtedly unusual, soft law may, however, serve as a kind of code of conduct in particularly complex cases, allowing the sphere concerning the application of legal provisions to be evaded, and thus to overcome the impasse. In order to better understand the substitution function of soft law, let us consider a resolution. In the absence of a sufficient amount of time needed to prepare the legal text or even the final shape of the agreement on all the proposed provisions, the parties concerned

M. Bothe, Legal and non-legal norms. A meaningful distinction in international relations, "Netherlands Yearbook of International Law"1980, pp. 65-95.

9 On the erosion of the sources enumerated in Article 38 of the ICJ Statute, v. R.-J. Dupuy, observateur de la première heure du phénomène de la soft law, constate: "Si les âges classiques sont ceux des distinctions nettes entre catégories précises, l'effritement des colonnes du temple de la loi érigé par l'article 38 du Statut de la Cour exprime assez bien un des aspects des mutations de la société internationale du temps présent." R.-J. Dupuy, Droit déclaratoire et droit programmatoire - de la coutume sauvage à la "soft law", in Communication. Colloque de Toulouse de la Société française pour le droit international, 16-18 mai 1974, p. 1. Cf. Declaratory Law and Programmatory Law: From Revolutionary Custom to "Soft Law", in Declarations on Principles, a Quest for World Peace (Liber Röling), ed. R.J. Akkerman, P.J. Van Krieken, Ch.O. Pannenborg, Leyden 1977, pp. 247-257. Cf. I.D. Seiderman, Hierarchy in International Law: The Human Rights Dimension, Antwerp 2001, p. 13.

$10 \mathrm{~F}$. Chatzistavrou, L'usage du soft law dans le système juridique international et ses implications sémantiques et pratiques sur la notion de règle de droit, "Le Portique" 2005, vol. 15, http://leportique. revues.org/591. 
may, in accordance, decide to adopt the resolution. This element may contribute to the adoption of a temporary solution, which will later on be confirmed on the basis of hard law and replace the temporary soft law solution, which had a controversial form in any case. Finally, in addition to the two aforementioned features, a solution adopted on the basis of soft law can function as a companion act to institutionalization when the matters concerned overlap, but they cannot be dealt with using the same legal tools (we then talk about the additional role played by soft law). All three features described above place emphasis on the two main features of soft law, namely its imperative procedural aspect (requirements in terms of the need for this type of solution are not strict) and its "influential" nature. Both of these features may at first glance seem incompatible because of their coexistence with all its specifics. ${ }^{11}$ With regard to the first instruments characterized as "light," it can be said that the fact there is a decision to choose one of these subsidiary legal instruments is also evidence of a reluctance to submit to the legal restrictions of hard law, due to the introduction of short and simplified decision-making procedures. The results achieved by referring to this kind of soft procedure would possibly be difficult to obtain under the procedures of hard law. Soft law, through its more or less programmatic nature, also creates a framework for future discussions and negotiations between states.

In this context it is possible to focus on the purely „symbolic” use of available possibilities, in order to avoid having to take decisions of a binding nature, which are thus likely to entail serious legal consequences. This solution makes it possible to establish a framework covering the individual, intermediate stages to reach a consensus and make a decision based on obtaining clean consent. This makes it quite obvious that it is easier for states to express their consent to the act, which has consequences in the form of legal obligations on a small scale. Consent also reflects the political interests of the parties that want in this way to demonstrate their support for specific fields of policy, and at the same time can do so without being involved at a purely legal level and without making any pretense or imposing on each other's specific rights and responsibilities. ${ }^{12}$

11 C.M. Chinkin, The Challenge of Soft Law : Development and Change in International Law, "The International and Comparative Law Quarterly" 1989, vol. 38, p. 860. Cf. M. Fitzmaurice, The Identification and Character of Treaties and Treaty Obligations between States in International Law, "British Yearbook of International Law" 2002, vol. 73, p. 180.

12 For exemple the Rio principle 7 "States shall cooperate in a spirit of global partnership to conserve, protect and restore the health and integrity of the Earth's ecosystem. In view of the different contributions to global environmental degradation, States have common but differentiated responsibilities. The developed countries acknowledge the responsibility that they bear in the international pursuit to sustainable development in view of the pressures their societies place on the global environment and of the technologies and financial resources they command." See, e.g., Convention on Long-Range Transboundary Air Pollution (Geneva, 13 Nov. 1979), 1302 U.N.T.S. 217, art. 1. V. also: Vienna Convention for the Protection of the Ozone Layer (Vienna, 22 Mar. 1985), UNEP Doc. IG.53/5, art.1(2); Montreal Protocol on Substances 
Thus, as we have seen, when an act situates itself in the sphere of soft law, it sometimes leads to the adoption of subsequent acts of a compulsory nature, which constitutes a first step towards developing a political consensus. Because the obligation arising under the agreement or contract concluded on the basis of soft law is a mainly a political or moral obligation, the resulting penalties and legal consequences are negligible. The fact there is no compulsory jurisdiction on certain rules of conduct allows states to make interpretations of their own, the fact being that it may sometimes be very convenient to removes some acts from the jurisdiction of the judiciary. For example, many of the provisions contained in the various codes of conduct defining international rules entail legal sanctions due to insufficient clearly formulated content or the same type of conduct under regulation. In this context, there arises not only the danger resulting from differences of interpretation, but, more importantly, the danger of possibly violating the law, against which there would be no possibility of appeal. An international agreement, generating political, moral and legal consequences, must be approved by parliament. While the act of holding a political and moral obligation often includes relevant legal and characterizes at the same time, a certain degree of precision and specialization, is not subject de facto to this procedure. However, it is the responsibility of each country to make a final assessment by reference to the constitutional law applicable on its territory, because the extent to which it can dispense with the procedure depends on parliamentary ratification. Thus, for example, a specific agreement in one country might require the consent of parliament if it is to enter into force, another may well be included under the sole responsibility of the government. Acts governed by the rules of soft law contain a type of conditional or absolute clause ratification. Placing a conditional clause is evidence of some kind of flexibility. Nevertheless, even in the case of a clause, absolute application of the procedure for the implementation of the act is simpler than the procedure that usually takes place in the case of agreements and international law, which does not provide for the exchange of instruments of ratification. Mitigated, the nature of the procedure goes hand in hand with the "influential" nature of soft law. This seemingly paradoxical state of affairs testifies to the rank the soft law enjoys in international com-

that Deplete the Ozone Layer (Montreal, 16, Sept. 1987), 26 I.L.M. 1550 1987), Pmbl, § 3; Convention on the Transboundary Effects of Industrial Accidents (Helsinki, 17 Mar. 1992), 31 I.L.M.1330, art. 1(c); United Nations Framework Convention on Climate Change (Rio de Janeiro, 9 May 1992), 31 I.L.M. 849, art. 1(1); Convention on the Protection of the Marine Environment of the Baltic Sea Area (Helsinki, 22 Mar. 1974), 13 I.L.M. 546, art. 2(1); Convention for the Prevention of Marine Pollution from Land-Based Sources (Paris, 4 June 1974), 13 I.L.M.352, art. 1; Convention for the Protection of the Mediterranean Sea against Pollution (Barcelona, 16 Feb. 1976), 15 I.L.M. 290, art. 2(a) and all subsequent regional seas agreements; Convention on the Non-Navigational Uses of International Water courses (New York, 31 May 1997), 36 I.L.M. 700, art. 21(2). 
munication or exchange, in spite of its only slightly binding nature. It is worth noting that in describing soft law as "influential," we refer to an act regulating the principles of soft law outside its legal value in the strict sense of the word. An act is characterized by low binding power from a legal point of view, it may be quite binding politically and exert a strong influence on the international arena as a means of political pressure. For example, the opposition of a Member State to a particular act may force the State to remain on the defensive, entailing the need to clarify the position they occupy. But the act which regulated the principles of soft law may also be part of initiating the operation of a particular norms; a situation of this kind took place even in the case of the Universal Declaration of Human Rights. Finally, the act of belonging to the sphere of soft law may establish guidelines in previously pristine areas - guidelines which are designed to prevent such practices from occurring in a state based on selfish sovereignty. Both of the aforementioned features which characterize soft law, i.e either its mild or lighter nature and its "influential" character, reflect differences between the flexibility offered by the procedure and opacity in the impact of strength. Internationally, the dominant area of use and the application of soft law is the area of executive power. In this context, there is a paradoxical contrast between, on the one hand, the high levels of state authorities entitled to sign or approve arrangements made based on the criteria of soft law (heads of state and prime ministers, foreign ministers or other ministers, diplomats, or, in the case of when it is allowed, other officials), involving reciprocal obligations and justified represented in this way, and, on the other hand, the non-binding nature of these obligations of the states. Regardless of any legal dilemmas that inspire the practice of soft law from the point of view of procedural and conceptual practice, it is constantly growing and evolving, becoming an essential instrument for the exercise of political power.

In light of the above, the paradox resulting from the frequent use of soft law can thus be summarized as follows: As soft law is turned to more and more often, an has fartherreaching application, the strengthening of its legal and political status allows national governments to use an even wider range of its features in newer areas of activity in the international arena. By expanding the area of the application of soft law, which results primarily from legal tolerance, government actions are freed from coercion, parliamentary oversight and jurisdiction, and can thereby shape political decisions at various international forums. In other words, despite the fact that acts concluded on the basis of the principle of soft law contain provisions about their specified range, legal acts are carried out without being subject to the requirements of the law in the case of international mechanisms - such as judicial review and mandatory approval by parliament - which essentially would be required by the rule of international law. The fact that these acts are carried out in isolation from the limitations of the existing international mechanisms gives governments considerable leeway to help them make joint decisions. Thus, the 
increasing use of soft law instruments creates legal incentives for the creation and operation of a new type of rights. ${ }^{13}$

On the one hand, the use of soft law may be seen as a manifestation of the fact that the decision-making structures operating at the international level do not have transnational decision-making power, yet on the other hand it can also be understood as a kind of loophole in the area of cooperation between countries, which could provide a practical solution for the need to strengthen international legal order, where it shows a certain weakness or turns out to be simply ineffective. ${ }^{14}$ Soft law is a kind of gentlemen's agreement binding the parties, which increases the flexibility of their activities with regard to the political governance of their behavior or gives direction to their future actions. It is particularly appropriate in situations of insufficient competence and when there is difficulty in reaching a consensus. However, the risk of abuse of power in relation to the restrictions laid down by treaties, essentially for political reasons, might frustrate both the course implicitly recommended and the current decision-making procedure. ${ }^{15}$

\section{The permissive nature of the international legal system in the face of the development of soft law}

The blurred distinction between the nature of this international legal and political instrument raises the issue of border demarcation, which separates the doctrinal point of view of the field of public international law and international relations. Some legal experts point out that the use of soft law in some way carries the risk of the "juridification" of international political relations. The development of specific standards at the international level is associated with a number of problems of a legal, political and technical nature. Paradoxically, the use of soft law is developing in a dynamic way, although this is not due to lack of precise provisions in the treaties relating to the policy area. In the doctrine, the introduction of the concept of soft law was considered as an attempt to discourage countries from benefitting from hard law. "Infra-juridical" practices,

13 J. Klabbers, The Redundancy of Soft Law, "Nordic Journal of International Law" 1996, vol. 65, p. 167. Cf. N. Luhmann, La confiance: un mécanisme de réduction de la complexité sociale, transl. S. Bouchard, L.K. Sosoe, Paris 2006; S. Beci, Environmental Protection in the Framework of International Law: Development and Perspectives, "European Scientific Journal" 2014, vol. 22, pp. 31-42; C.M. Chinkin, op. cit., pp. 850-866.

14 K.W. Abbott, R.O. Keohane, A. Moravcsik, A.-M. Slaughter, D. Snidal, The Concept of legalization, "International Organization" 2000, vol. 54, no. 3, pp. 401-419; K.W. Abbott, D. Snidal, Hard and soft law in international governance, "International Organization" 2000, vol. 54, no. 3 , p. 453.

15 T. Olawale Elias, op. cit., p. 49; H. Thierry, Les résolutions des organes internationaux dans la jurisprudence de la Cour internationale de Justice, "Recueil des Cours de l'Académie de Droit International" 1980-II, vol.167, p. 442. 
characterized by permissiveness in the application of the general principles of international law, raise the concern that acts governed by the rule of soft law will replace the legal forms in their strict sense, which alone can guarantee the adoption of provisions which are supposed to be legally binding. ${ }^{16}$ Thus, there is a fear that acts of soft law will supplant the legal forms which alone can adopt legally binding provisions. When it comes to counteracting the propensity of actors (both public and private) to go it alone and, for the most powerful, to turn rules to their advantage, or even to seek to define them according to their own interests, international law may prove to be ineffective by favoring the use of non-binding acts. However, not forgetting the above risk of "juridification" in international political relations through these "infra-juridical" practices, the law can possibly evolve or even change in the customary manner. Normative diversification, which carries a soft law raises the problem of qualification and classification standards derived from these "infra-juridical" practices. Is soft law a normative category situated between the law and lawlessness? The prioritization of normative sources leads to imposing a formal order of priorities, so that conformity with the former constitutes the criterion of legality of the latter. A relatively orderly and rational rearrangement of the various acts practiced within the international legal system, without being tied to the definition of a prior hierarchy between them, would allow a distinction to be made based on their function and on the authority from which they derive. However, the variety of international "legalization" with which we are dealing shows that there is a missing hierarchy of norms and a source directory explicitly incorporated into texts; this is the consequence of the choices made by the international legal order. The pyramidal concept of the hierarchy of norms (in terms of consistency and uniformity of the law by $\mathrm{H}$. Kelsen) has been replaced by fuzzy standards, which lack clearly marked boundaries (the so-called «distributed» concept of law).

\section{Conclusion}

Acts are defined through the prism of their structures and effects, but in the global hierarchy occupied by each of them on the basis of the mutual relationship existing between them, their legal status is no longer clear. The use of one or other types of act is not associated with an existing possible difference between them in terms of legal status, but with the function and objectives, which is to be achieved with their help. Going beyond the concept assumes that the law implies the existence of a hierarchical

16 D. Trubek, L. Trubek, The Coexistence of New Governance and Legal Regulation: Complementarity or Rivalry?, Paper presented at the Annual Meeting of the Research Committee on the Sociology of Law, Paris 2005, www.reds.msh-paris.fr/communication/docs/trubek.pdf [access: 31.07.2015]; A. Peters, Soft law as a new mode of governance, in The Dynamics of Change in EU Governance, ed. U. Diedrichs, W. Reiners, W. Wessels, Northampton 2011, p. 35. 
system of normative functioning at the international level, meaning that the law can be defined not only as a system of a compulsory nature, but also as a system of a contractual nature. In the case of soft law, perhaps, one should speak not so much about legal rules, or what rules of conduct are agreed on by the parties in accordance with their wishes. Given the fact that these rules are not considered a source of legal obligations, they are rather a factor than a source of law. They activate the function of a political party, which is the exercise of authority in the field of "justifying and convincing." Given H. Kelsen's normativist view which holds that it is sufficient for a rule of law to prescribe that its violation should be punished for it to be considered a legal provision, this transfer to a right devoid of coercion or of a contractual nature, which results from soft law being used with increasing frequency, proves that it is necessary to separate the notion of the legal system from the notion of a legal penalty. In fact, the application of sanctions is a prerequisite for the effectiveness of the law, not its existence. In other words, the concept of coercion and consequently, the notion of sanctions is not a constitutive element, but a functional element of the international legal system. In the international context the question of international responsibility of the public subjects is of even more fundamental importance than ever before.

\section{Literature}

Abbott K.W., Keohane R.O., Moravcsik A., Slaughter A.-M., Snidal D., The Concept of legalization, "International Organization" 2000, vol. 54, no. 3.

Abbott K.W., Snidal D., Hard and soft law in international governance, "International Organization” 2000, vol. 54, no. 3.

Andorno R., The Invaluable Role of Soft Law in the Development of Universal Norms in Bioethics, Paper at a Workshop jointly organized by the German Ministry of Foreign Affairs and the German UNESCO Commission, Berlin 2007, www.unesco.de/.

Atapattu S., International Environmental Law and Soft Law: A New Direction or A Contradiction?, in Non-State Actors, Soft Law and Protective Regimes from the Margins, ed. C.M. Bailliet, Cambridge 2012.

Baxter R.R., International Law in "Her Infinite Variety", "The International and Comparative Law Quarterly"1980, vol. 29, no. 4.

Beci S., Environmental Protection in the Framework of International Law: Development and Perspectives, "European Scientific Journal" 2014, vol. 22.

Bothe M., Legal and non-legal norms. A meaningful distinction in international relations, "Netherlands Yearbook of International Law" 1980.

Boyle A.E., Some Reflections on the Relationship of Treaties and Soft Law, "The International and Comparative Law Quarterly"1999, vol. 48. 
Chatzistavrou F., L'usage du soft law dans le système juridique international et ses implications sémantiques et pratiques sur la notion de règle de droit, "Le Portique" 2005, vol. 15, http://leportique.revues.org/591.

Chinkin C.M., The Challenge of Soft Law: Development and Change in International Law, “The International and Comparative Law Quarterly"1989, vol. 38.

Declaratory Law and Programmatory Law: From Revolutionary Custom to "Soft Law", in Declarations on Principles, a Quest for World Peace (Liber Röling), ed. R.J. Akkerman, P.J. Van Krieken, Ch.O. Pannenborg, Leyden 1977.

Diallo B.S., The role and place of soft law in the international legal system, in Wybrane problemy prawa materialnego i procesowego. Teoria i praktyka, ed. K. Konopka, J. Mucha, vol. IV, Poznań 2016.

Dupuy P.M., Soft Law and the International Law of the Environment, "Michigan Journal of International Law"1991, vol. 12.

Dupuy R.-J., Droit déclaratoire et droit programmatoire - de la coutume sauvage à la "soft law", in Communication. Colloque de Toulouse de la Société française pour le droit international, 16-18 mai 1974.

Dupuy R.-J., La technique de l'accord mixte utilisée par les Communautés européennes, "Annuaire de l'Institut de droit international" 1973.

Fitzmaurice M., The Identification and Character of Treaties and Treaty Obligations between States in International Law, "British Yearbook of International Law" 2002, vol. 73.

Klabbers J., The Redundancy of Soft Law, "Nordic Journal of International Law" 1996, vol. 65 .

Klabbers J., The Undesirability of Soft Law, "Nordic Journal of International Law" 1998, vol. 67.

Lachs M., Some Reflections on Substance and Form in International Law, in Transnational Law in a Changing Society - Essays in Honor of Philip C. Jessup, New York - London 1972.

Luhmann N., La confiance: un mécanisme de réduction de la complexité sociale, transl. S. Bouchard, L.K. Sosoe, Paris 2006.

Olawale Elias T., Modern Sources of International Law, in Transnational Law in a Changing Society - Essays in Honor of Philip C. Jessup, New York - London 1972.

Pellet A., Le "bon droit" et l'ivraie - Plaidoyer pour l'ivraie (Remarques sur quelques problèmes de méthode en droit international du développement), in Le droit des peuples à disposer d'eux-mêmes. Méthodes d'analyse du droit international. Mélanges offerts à Charles Chaumont, Paris 1984.

Peters A., Soft law as a new mode of governance, in The Dynamics of Change in EU Governance, ed. U. Diedrichs, W. Reiners, W. Wessels, Northampton 2011.

Riedel E., Standards and Sources. Farewell to the Exclusivity of the Sources Triad in International Law?, "European Journal of International Law” 1991, vol. 2. 
90 | Adam Mickiewicz University Law Review

Roessler F., Law, de facto agreements and declarations of principle in international economic relations, "German Yearbook of International Law" 1978.

Seiderman I.D., Hierarchy in International Law: The Human Rights Dimension, Antwerp 2001.

Skubiszewski K., The elaboration of general multilateral conventions and of non-contractual instruments having a normative function or objective, "Annuaire de l'Institut de droit international" 1985, vol. 61(1).

Thierry H., Les résolutions des organes internationaux dans la jurisprudence de la Cour internationale de Justice, "Recueil des Cours de l'Académie de Droit International" 1980-II, vol. 167.

Trubek D., Trubek L., The Coexistence of New Governance and Legal Regulation: Complementarity or Rivalry?, Paper presented at the Annual Meeting of the Research Committee on the Sociology of Law, Paris 2005, www.reds.msh-paris.fr/communication/ docs/trubek.pdf [access: 31.07.2015].

Virally M., La distinction entre textes internationaux ayant une portée juridique entre leurs acteurs et textes qui en sont dépourvus, "Annuaire de l'Institut de droit international" 1983, vol. 60-I, II.

Virally M., Sur la notion d'accord, in Festschrift fûr Rudolf Bindschedler (Mélanges), ed. E. Diaz, Bern 1980.

Wellens K.C., Borchardt G.M., Soft law in European Community law, "European Law Review"1989, vol.14, no. 1.

\section{SUMMARY}

\section{The Binding Force of International Legal Standards in the Face of the Recurrent Practice of Soft Law}

Soft law facilitates cooperation between international actors. Already, the elaboration of international law is a matter of shared competence between States, traditionally recognized as the only subjects of international law, international organizations and the typical actors. International organizations have initiated a movement towards the adoption of flexible forms of regulation of international relations. They will profoundly change the way in which international law will be created and presented to the recipients of the rule of law. From the very beginning of their activities, organizations preferred a method other than hierarchical command to encourage international cooperation. They will develop a consistent legal technique, aimed at persuading and not compelling their Member States to adopt conduct consistent with the legally binding standard. This article proposes a reflection on soft law and the results of its increasing use in international practices. 
Keywords: soft law, binding, international, legal standards, actors, cooperation

Boubacar Sidi Diallo, Adam Mickiewicz University Poznań, Faculty of Law and Administration, Al. Niepodległości 53,61-714 Poznań, e-mail: diallo@amu.edu.pl. 